\title{
Alteration in the Levels of Neutrophils and Lymphocytes in Male Wistar Rats (Second-Hand Smoker) with Marigold Leaves (Cosmos caudatus Kunth.)
}

\author{
Fitri Komala Sari ${ }^{1}$, ${ }^{*}$ Fathimah1, Hafidhotun Nabawiyah ${ }^{1}$, Sartika Amanda Putri ${ }^{1}$, \\ Retno Ayu Nurhayatun ${ }^{1}$
}

\begin{abstract}
${ }^{1}$ Department of Nutrition, Faculty of Health Science, University of Darussalam Gontor, Ngawi Indonesia ${ }^{*}$ Corresponding author.Email: fitri.ks@unida.gontor.ac.id
\end{abstract}

\begin{abstract}
The second-hand smoker will have difficulties because of nicotine and other substances leading to activate free radical in the body and stimulate the secretion of inflammatory mediators. Flavonoid is a compound contained in marigold leaves, believed to have anti-inflammatory effects. This study aims to look at the effect of marigold leaves to neutrophil and lymphocyte profile of Wistar rat exposed cigarette smoked. This research was an experimental laboratory research design with pre and post-control groups. The sample consisted of 30 male Wistar rats. The control group was given food and drink in an ad libitum without given marigold, while treatments group 1 and 2 were given marigold at a dose of 4.5 and 6.3 grams, respectively. Each group was exposed to 2 cigarettes smoked per day for 2 weeks. On days 0,7 , and 14, blood samples were taken through retro orbitals. The data were analyzed by using the Sysmax KX-21® Hematology Analyzer. Normality test used Shapiro-wilk continued to one way ANOVA test and finally DUNCAN test. One way ANOVA test results for neutrophils and lymphocytes stated $p=0.00$, which means that the effect of giving marigold to levels of neutrophils and lymphocytes of Wistar rats exposed cigarette smoked, the DUNCAN test results stated the dosage of 4.5 and 6.3 not significantly different but gave a significant difference to the control group. Marigold significant to reduce levels of neutrophils and lymphocytes to the normal stage of wistar rats exposed cigarette smoked.
\end{abstract}

Keywords: Cigarette smoke, Lymphocyte, Marigold leaves, Neutrophil

\section{INTRODUCTION}

There are $33.8 \%$ of people in Indonesia consume tobacco, some of them consume as cigarettes such as kretek, linting, white cigarette, electric, and sisha. More than $20 \%$ in every province smoke in a room making another's become second-hand smoker [1]. The secondhand smoker is someone who not smoking but inhaling cigarette smoke will get some problem in their body because of nicotine and other substances that become free radical in the body and stimulate the secretion of inflammatory mediators.

Cigarette smoke contains around 5000 compounds. 98 components were a hazardous component that has potential health risk on cancer and non-cancer [2], as well as Type 2 Diabetes Mellitus (T2DM) [3]. Chronic Obstructive Pulmonary Disease (COPD) such as asthma [4], decrease cardiovascular function, atherosclerosis, and increasing LDL levels [5]. The main toxins in cigarettes are nicotine, carbon monoxide, aldehyde compounds and aromatic hydrocarbons. Nicotine is a toxic alkaloid compound, can cause addiction, and depression in both active and passive smokers [6].

Leukocytes especially lymphocyte and monocytes can enter tissues (macrophages) and secrete cytokines which act as couriers to influence the body's immune response. Exposure to free radicals in cigarette smoke will increase cytokines and stimulate the release of neutrophils. An increase in neutrophils in the blood is called neutrophil [7]. Levels of white blood cells, neutrophil, and lymphocyte increase in smokers [8].

Sources of natural antioxidants, including flavonoid, are generally from plants. Flavonoid is one of the aromatic group compounds and secondary metabolites which are included in the polyphenol group. Both 
compounds have almost the same properties such as antioxidant, anti-inflammatory, anti-carcinogen, antivirus, antitumor and can inhibit neurodegenerative diseases. Flavonoids can also inhibit lipid peroxidation and fragilita [9].

Marigold leaves (Cosmos caudatus Kunth.) is one type of vegetable that commonly consume in Indonesia as lalap or pecel. Some people consume it in raw and some cooked before eating. Marigold leaves containing antioxidant compounds like flavonoid and phenolic [10]. The largest type of flavonoids found on Marigold leaves is quercetin in the amount of $1225.88 \mathrm{mg}$ per $100 \mathrm{~g}$ dry weight. Leaves marigold can be used as a bioinsecticide in plants to eradicate pests. Leaves Marigold by some people is often consumed as fresh vegetables. Other than that, marigold leaves have long been used by the community in everyday life as an appetite enhancer [11].

Neutrophil and Lymphocytes profile functions in the body's defense system against antigens that infect the body of test animals related to the provision of exposure to cigarette smoke. For this reason, what is expected from this study is the administration of Marigold treatment for 14 days to rats exposed cigarette smoked can reduce the profile of leukocytes (neutrophils and lymphocytes) at the lower limit of the normal range. The aim of this study is proving the effect of marigold leaves (Cosmos caudatus Kunth.) on the decreased of levels neutrophils and lymphocytes in wistar rats (Rattus norvegicus) exposed cigarette smoke.

\section{MATERIAL AND METHOD}

\subsection{Material}

Marigold leaves were obtained from the Yogyakarta traditional market, then the leaves are separated from the stem. The clove cigarette smoke with a tar content of 39 $\mathrm{mg}$ and nicotine $2.5 \mathrm{mg}$ per cigarette as a testing material, Aquades as a marigold leaves when blending.

\subsection{Animal}

The subjects of the study were 30 Wistar rats aged 68 weeks by weight $150-200$ grams. For approximately one week before using animals acclimatized to the laboratory environment. During the maintenance, experimental animals were given enough food and drink. Rat placed individually in a cage made of plastic cages measuring $30 \times 20 \times 12 \mathrm{~cm}$ and it was equipped with wire screens on the part upon it. Cages placed in the higher rows must be closed to protect animals from excessive light exposure because they could cause retinal changes in albinotic animals. Rat space was usually guarded at 30$70 \%$ relative humidity and a temperature of $18-26^{\circ} \mathrm{C}$ with at least 10 hourly room air changes.
The dosage of Marigold leaves given to animals was determined based on the daily consumption of fruits and vegetables that was equal to 400-600 grams per person per day and two-thirds of the recommended amount of consumption is the portion of vegetables [12]. This dosage was converted to a dose for rat determined at 70 $\mathrm{kg}$ human weight and 200-gram rat. Based on the calculation of dose conversion, the value of dose conversion for humans to the rat was 0.018 . So that the consumption of vegetables for humans 250 grams per day, for rat to $250 \times 0.018$ grams per day or 4.5 grams per day, and vegetable consumption for humans 350 grams per day, for rat to $350 \times 0.018$ grams per day or 6.3 grams per day. By using 2 doses of variation, animals were grouped into 3 groups, each of which consisted of 10 heads, namely: group I (positive control) only fed normal rat. Group II and III were given additional Marigold leaves (4.5 and 6.3) gram / kgBW, Marigold given to each treatment groups 1 and 2 were $10 \mathrm{ml}$, feeding to rats used the sonde method [13].

Cleaning of rat's cages was carried out every day. The garbage and rats feces were disposed at the disposal site of experimental animal waste to prevent environmental pollution. At the end of the experiment, the rats were decapitated with ether anaesthesia.

\subsection{Cigarette Smoke Exposure}

Exposure to cigarette smoke was done every day by putting rats in a box measuring $30 \mathrm{~cm} \mathrm{x} 40 \mathrm{~cm} \times 50 \mathrm{~cm}$ with a ventilation size of $5.6 \mathrm{~cm} \times 28.4 \mathrm{~cm}$. Burnt cigarettes were a type of non-filtered kretek brand "D" with a tar content of $2.5 \mathrm{mg}$ and nicotine $39 \mathrm{mg}$ per stick. exposure to cigarette smoke for 30 minutes every day [14].

\subsection{Treatment and Observation}

The treatment was given for 14 days with a frequency of 1 times pellet administration, and weigh the remaining pellets every day. For blood collection done on the day to 0 continued on days 7 and 14, Blood was drawn from the retro-orbital sinus used a hematocrit capillary, accommodated inward microtube. Determination of the haematological profile used the Sysmax KX-21® Hematology Analyzer. Results obtained were: neutrophils and lymphocytes profile.

\subsection{Data Analysis}

Data was presented in the form of quantitative analysis. Data obtained used the One Way ANOVA Test, to find out the differences in each treatment, and further tests with Duncan's 95\% confidence level test or $=0,05$. This study submitted to the research ethics commission Faculty of Medicine, the University of Muhammadiyah Surakarta with number 2651/A.1/KEPKFKUMS/IX/2019. 
Table 1. The Result of Neutrophil

\begin{tabular}{|c|c|c|c|c|c|c|c|}
\hline \multirow{2}{*}{ Group } & \multicolumn{3}{|c|}{ Neutrophil (\%) } & \multirow{2}{*}{$\begin{array}{c}\Delta 1 \\
(\text { Mean } \pm \text { SD })\end{array}$} & \multirow{2}{*}{$\begin{array}{c}\Delta 2 \\
(\text { Mean } \pm \text { SD })\end{array}$} & \multirow{2}{*}{$\mathbf{P}^{*} \mathbf{1}$} & \multirow{2}{*}{$P * 2$} \\
\hline & I & II & III & & & & \\
\hline $\mathrm{K}$ & 24 & 26 & 35 & $2,0 \pm 1,3^{\mathrm{a}}$ & $10,44 \pm 2,4^{\mathrm{a}}$ & & \\
\hline $\mathrm{P}_{1}$ & 29 & 23 & 22 & $-5,8 \pm 2,0^{b}$ & $-6,5 \pm 1,4^{b}$ & 0,000 & 0,000 \\
\hline $\mathrm{P}_{2}$ & 36 & 22 & 19 & $-13,6 \pm 4,7^{b}$ & $-16,4 \pm 6,1^{\mathrm{b}}$ & & \\
\hline
\end{tabular}

Description: $\mathrm{K}=$ Control group, $\mathrm{P} 1=4.5$ grams herbal treatment group, $\mathrm{P} 2=6.3$ grams herbal treatment group, $\mathrm{P} *_{1} \& \mathrm{P} *_{2}=$ One-way ANOVA, ${ }^{\mathrm{a}}=$ Post hoc analysis subset $1,{ }^{\mathrm{b}}=$ Post hoc analysis subset 2

\section{RESULT}

There were different levels of neutrophil and lymphocytes of male wistar rats exposed cigarette smoked after treated by Marigold leaves.

The average neutrophil calculation data on days 0,7 and 14 in each group were presented in Table 1. One way ANOVA analysis results obtained $(\mathrm{p}=<0.00$ or $\mathrm{p}=<0.05)$ can be concluded that $\mathrm{HO}$ was rejected or there was an effect of giving Marigold leaves to neutrophil values. The treated rat showed consecutive decreases in neutrophil levels. The used of Marigold leaves with different doses did not show any significant difference $(p>0.05)$, which means that Marigold leaves with a dose of 4.5 grams and 6.3 grams had almost the same effect in reducing leukocyte levels to normal levels.

Data on the average lymphocyte count on days 0,7 and 14 in each group can be seen in Table 2. One way ANOVA analysis results obtained $(\mathrm{p}=<0.000$ or $\mathrm{p}=<0.05)$ can be concluded that $\mathrm{HO}$ was rejected or there is an effect of giving Marigold leaves to the value of lymphocytes. The treated rat showed a decrease in lymphocytes consecutively. The use of Marigold leaves with different doses did not show any significant difference $(p>0.05)$, which means that Marigold leaves with a dose of 4.5 grams and 6.3 grams had almost the same effect in reducing leukocyte levels to normal levels.

\section{DISCUSSION}

This study used a pre-post-test design control group design. The study was conducted in December 2019 to January 2020. Maintenance and treatment of cigarette smoke exposure were carried out in the Laboratory of Food and Nutrition Study Center Universitas Gadjah
Mada Yogyakarta, while for the examination of total leukocyte levels carried out at LPPT Universitas Gadjah Mada Yogyakarta. Male wistar rats were used as samples with inclusion criteria 6-8 weeks old with a weight ranging from 150-250 grams, the rat in good health and could receive treatment according to the research procedure. For the influence of gender, the use of male rats because there is an interest in seeing sex, does not affect hormones exposed cigarette smoked.

Exposure cigarette smoke can increase total white blood cells levels due to inflammation of substances in cigarette smoke. Cigarette smoke is a type of exogenous free radicals that contain more than 5,000 components of toxic and carcinogenic chemicals, such as nicotine, nitrogen oxides, carbon monoxide, hydrogen cyanide and other free radicals. Every breath of cigarette smoke contains free radicals. Exposure cigarette smoke can cause the body to experience a state of oxidative stress and an increase in total leukocytes as a sign of inflammation. Based on the results of this study, groups of rats that were only given exposure to cigarette smoke showed the highest value of leukocyte levels among the other treatment groups [15].

Marigold, one of the vegetables that consume in Indonesia was reported has some pharmacological properties, such as antioxidant, anti-inflammatory, antihypertensive, hepatoprotective, anti-diabetic, antiosteoporosis, and detoxification [16]. Phenolic and flavonoid compound in marigold leaves reported as antioxidant agent [17].

Giving and marigold aim as an anti-inflammatory agent caused by exposure to cigarette smoke. This was indicated by the average value of the treatment group showing that there was a decrease in the number of leukocytes, neutrophils, and lymphocytes after giving Marigold leaves.

Table 2. The Result of Lymphocyte

\begin{tabular}{|c|c|c|c|c|c|c|c|}
\hline \multirow{2}{*}{ Group } & \multicolumn{3}{|c|}{ Lymphocytes (\%) } & \multirow{2}{*}{$\begin{array}{c}\Delta 1 \\
(\text { Mean } \pm \text { SD) }\end{array}$} & \multirow{2}{*}{$\begin{array}{c}\Delta 2 \\
(\text { Mean } \pm \text { SD })\end{array}$} & \multirow{2}{*}{$P * 1$} & \multirow{2}{*}{$P * 2$} \\
\hline & I & II & III & & & & \\
\hline $\mathrm{K}$ & 68 & 80 & 98 & $12,2 \pm 1,1^{\mathrm{a}}$ & $29,88 \pm 1,31^{\mathrm{a}}$ & & \\
\hline$P_{1}$ & 94 & 82 & 71 & $-11,6 \pm 7,6^{b}$ & $-9,8 \pm 6,8^{b}$ & 0,000 & 0,000 \\
\hline $\mathrm{P}_{2}$ & 96 & 78 & 53 & $-17,88 \pm 7,97^{b}$ & $-43,33 \pm 4,9^{b}$ & & \\
\hline
\end{tabular}

Description: $\mathrm{K}=$ Control group, $\mathrm{P} 1=4.5$ grams herbal treatment group, $\mathrm{P} 2=6.3$ grams herbal treatment group, $\mathrm{P} *_{1} \& \mathrm{P} *_{2}=$ One-way ANOVA, ${ }^{\mathrm{a}}=$ Post hoc analysis subset $1,{ }^{\mathrm{b}}=$ Post hoc analysis subset 2 
Male wistar rats were used as samples with inclusion criteria 6-8 weeks old with a weight ranging from 150250 grams, rat in good health and could receive treatment according to the research procedure. For the influence of gender, the use of male rats because there is an interest in seeing sex, does not affect hormones exposed cigarette smoked.

The increase in neutrophils in treatment 1 and treatment 2 (Table 1) was in accordance with the theory which shows that an increase in the neutrophil release from the bone marrow to the area or location is inflamed so that during the first 2 hours an increase in neutrophils in peripheral blood can be found. The release of neutrophils in inflammatory tissue is a cell response where according to its function, neutrophils in the body will carry out phagocytosis, chemoctosis, and kill and digest inflammatory agents or foreign bodies in the body [18].

Leukocytosis or an increase in the number of white blood cells and one of them will also increase white blood cells with a type of neutrophil which plays a role in reducing inflammation in the body or called neutrophilia. The body will produce more white blood cells or leukocytes to increase immunity in maintaining the condition of the body. Increased white blood cell production will cause neutrophils in peripheral blood to increase to exceed the normal limit of neutrophil percentage values. The normal value of neutrophils in humans is in the range of 50 to $70 \%$ while in male wistar rats is $4.5 \%$ to $23.5 \%$. Neutrophils are a type of white blood cell that is a marker of inflammation. Neutrophils will work when there are signals from the cytokine hormone that indicate the location of inflammation in the body increasing the number of neutrophils in peripheral blood [20].

Continual exposure to second-hand smoke can increase the number of lymphocytes (Table 2), with one of the signs of foreign substances entering the body. Blymphocytes that function to make antibodies against antigen produced in bone marrow will increase, and Tlymphocytes produced in the thymus gland also will increase because it is responsible for killing viruses and bacteria directly. The accumulation and recruitment of lymphocytes that are constantly associated with plaque formation. These plaques are prone to rupture, causing thrombosis, myocardial infarction or stroke. A decrease in leukocyte count is expected to minimize this risk [21].

\section{CONCLUSION}

Marigold leaves can reduce levels of neutrophils and lymphocytes to the normal stage in male rats exposed cigarette smoked. Marigold leaves with a dose 4.5 grams and 6.3 grams have almost the same effect to reduce levels of neutrophils and lymphocytes to the normal stage in male rats exposed cigarette smoked.

\section{CONFLICT OF INTEREST}

The authors declare they have no conflict of interest

\section{ACKNOWLEDGMENTS}

This work was supported by Faculty of Health Science, University of Darussalam Gontor and Centre of Food and Nutrition Science, University of Gadjah Mada.

\section{REFERENCES}

[1] TCSC IAKMI, Atlas Tembakau Indonesia. Tobacco Control Support Center-Ikatan Ahli Kesehatan Masyarakat Indonesia. Jakarta, 2020

[2] R., Talhout, T. Schulz, E. Florek, J.V. Bethem, P. Wester, A. Opperhuizen, "Hazardous Compound in Tobacco Smoke", Int. J. Environ. Res. Public Health 8 (2011) 613-628, doi:10.3390/ijerph8020613.

[3] Y. A. Rias, C. J. Gordon, S. F. Niu, B. S. Wiratama, C. W. Chang, H. T. Tsai, "Secondhand Smoke Correlates with Elevated Neutrophil-Lymphocyte Ratio and Has a Synergistic Effect with Physical Inactivity on Increasing Susceptibility to Type 2 Diabetes Mellitus: A Community-Based Case Control Study", Int. J. Environ. Res. Public Health 17 (2020) 5696.

[4] B. H. Shnawa, S. J. Al-Ali, H. F. Ahmad, S. A. Essa, "An Investigative Study of Smoking Effects on IL31 Levels and Leukocyte differential counts in Humans". Annals of Tropical Medicine \& Public, 23 (2020) 1133, doi:10.36295/ASRO.2020.231133.

[5] G. Papathanasiou, A. Mamali, S. Papafloratos, E. Zerva, "Effects of Smoking on Cardiovascular Function: The Role of Nicotine and Carbon Monoxide", Health Science Journal, 8(2) (2014) 274

[6] M. Sihombing, I. T. Notohartojo, "Gambaran Sosiodemografi Perokok Pasif dengan ISPA dan Faktor yang Berpegaruh dengan Kejadian ISPA pada Balita di Indonesia (Analisis Data Riskesdas 2013)", Jurnal Ekologi Kesehatan, 14(4) (2017) 284-295

[7] E. Ruhimat, "Gambaran Diff Count Pada Perokok di Kecamatan Cibereum". Jurnal Kesehatan Tunas Bakti Husada, 12(1) (2015) 96-101.

[8] F. A. Aula, F. A. Qadir, "Effects of Cigarette Smoking on Some Immunological and Hematological Parameters in Male Smokers in Erbil City Jordan", Journal of Biological Science, 6(2) (2013) 159-166. 
[9] A. Sundaryono, "Uji Aktifitas Senyawa Flavonoid Total Dari Gynura Segetum Lour Terhadap Peningkatan Eritrosit Dan Penurunan Leukosit Pada Pada Mencit”, Jurnal Exaxta, 2(2) (2017) 8-16

[10] A. Werdhasari, "Peran Antioksidan Bagi Kesehatan”, Jurnal Biotek Medisiana Indonesia, 3(2) (2016) 59-68.

[11] T. Murningsih, A. Fathoni, "Evaluasi AKtivitas Anti-Inflamasi dan Antioksidan Secara In-Vitro, Kandungan Fenolat dan Flavonoid Total Pada Terminalia spp". Berita Biologi, 15(2) 2017 159166.

[12] A. Ardiansyah, R. Fadilah, D. D. Handoko, B. Kusbiantoro, R.M. Astuti, "Effect of Household Scale Heating on Bioactive Compound Kenikir Leaves (Cosmos caudatus)", Agritech, 39 (3) 2019, 207-214

[13] E. Mailisdiani, L. Santoso, \& Riyanto. "Efek Tonik Ekstrak Daub Kenikir (Cosmoss Caudatus Kunth) Terhadap Mencit Galur Sub Swiss Webster Serta Sumbangannya Pada Pembelajaran Biologi SMA”. Jurnal Pembelajaran Biologi, 3(2) (2016)

[14] Kementrian Kesehatan RI. Infodatin: Perilaku Merokok Masyarakat Indonesia, Jakarta, 2016

[15] Permatasari, Dwi, Nungki, "Efek pemberian jus batang nanas (Ananas comosus) terhadap profil leukosit tikus wistar yang di papar asap rokok", Journal of Nutrition College. 1(2)
[16] G. Sirih, J. Engka, \& S. Merunduh, "Hubungan merokok dan kadar leukosit pada perokok kronik", Jurnal Kedokteran Diponegoro, 5(2) (2017)

[17] E. W. C. Chan, S. K. Wong, H. T. Chan, "Ulam Herbs of Oenanthe javanica and Cosmos caudatus: An Overview on their Medicinal Properties", Journal of Natural Remedies, 16 (4) (2016) 137-147, doi: $10.18311 /$ jnr/2016/8370.

[18] N. Andarwulan, R. Batari, D. A. Sandrasari, B. Bolling, H. Wijaya, "Flavonoid content and antioxidant activity of vegetables from Indonesia", Food Chemistry, $121 \quad$ (2010) 1231-1235 doi:10.1016/j.foodchem.2010.01.033.

[19 R. Prihandari, L. Muniroh, “Jus semangka menurunkan neutrofil tikus jantan galur wistar yang terpapar asap rokok”, Media Gizi Indonesia, 11(2) (2017) 166-174

[20] A. Sari, Tjandrakirana, \& N. Kuswanti, "Pengaruh Jus Lidah Buaya (Aloe vera) Terhadap Jumlah Leukosit Pada Tikus Putih Yang Terpapar Asap Rokok", LenteraBio, 7(2) (2018) 159-162.

[21] S. Aisahi, Khotimah, "Pengaruh Polifenol Teh Hijau Terhadap Produksi Tnf-A (Tumor Necrosis FactorA) Pada Kultur Sel Trofoblas Manusia Yang Dipapar Glukosa Tinggi 33 MmI", Journal of Nutrition College, 2(2) (2016) 